Semmelweis Egyetem, Fogorvostudományi Kar, Arc-, Állcsont-, Szájsebészeti és Fogászati Klinika*

Department of Oral Surgery, Dental Institute, King's College, London (Anglia) ${ }^{\star *}$

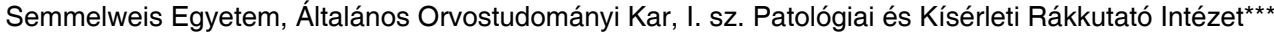

Egyesített Szent László és Szent István Kórház-Rendelőintézet, I. Infektológiai Osztály****

\title{
A sinus maxillaris mucormycosis fertőzésének diagnosztikai problémái
}

\author{
Esetbemutatás
}

DR. BÉRCZY KINGA*, DR. LŐRINCZ ÁDÁM**,
DR. FÓNYAD LÁSZIÓ***, DR. PRINZ GYULA****

\begin{abstract}
A mucormycosis fulmináns opportunista fertőzés, amely fogékony szervezetben jelentős mortalitással rendelkezik. A mortalitás különböző irodalmi adatok alapján 30 és 100\% közötti. Hajlamosító betegségek: diabetesz mellitusz, alultápláltság, hematológiai betegségek, neutropénia, égési sérülések, mútéti eljárások, antibiotikus kezelés, hosszú távú szteroid kezelés, és immunszuppresszív terápia. Megkülönböztetünk rhino-maxillaris és rhino-oculocerebralis formákat, utóbbira jellemző a magas halálozási arány. A prognózis gyors diagnózis felállítással, a terápia gyors megkezdésével és az alapbetegség kezelésével javítható. Bár a kórkép felismerésében, kezelésében elsősorban nem fogorvosoknak, szájsebészeknek van szerepe, de a betegség lokalizációja miatt differenciál diagnosztikai szempontból szükséges ismerni, valamint interdiszciplináris együttmúködésre szükség lehet a komplex kezelésben. Célunk a mucormycosis bemutatása saját esetünkön keresztül.
\end{abstract}

Kulcsszó: mucormycosis, sinusitis, invazív gombafertőzés

A mucormycosis ritka, invazív és agresszív opportunista gombafertőzés. A kórképet a Zygomycota (járomspórás gombák) törzsébe tartozó Zygomycetes osztályhoz tartozó Mucorales rend, Mucoraceae családjának gombafajai okozzák. A családon belüli nemzetségek: Absidia, Mucor, Rhizomucor, Rhizopus, Apophysomyces. Ezek közül is a Rhizopus fajok felelősek a legtöbb mucormycosis fertőzésért [11, 14]. Első leírója Paltauf volt, 1885-ben [10], az első ezzel kapcsolatos publikáció 1940-ben jelent meg. 1940 és 2003 között 929 esetet írtak le az angol nyelvú irodalomban [12], az első gyógyult esetről 1955-ben számoltak be [3]. Az Egyesített Szent István és Szent László Kórház-Rendelőintézetben 1992 és 2003 között 15, igazoltan mucormycosisban szenvedő beteget kezeltek [7]. A mortalitási mutatók az irodalmi adatok alapján [5, 9] széles skálán mozognak (30-100\%), azonban napjainkban a komplex terápiának köszönhetően, központi idegrendszeri (KIR) érintettség nélkül a túlélési arány $50-80 \%$. KIR érintettség esetén viszont a halálozási arány $80 \%$ feletti [15]. Hajlamosító tényezők: diabetesz mellitusz, alultápláltság, hematológiai betegségek, neutropénia, égési sérülések, mútéti eljárások, antibiotikus kezelés, hosszú távú szteroid kezelés, és immunszuppresszív terápia. Mucormycosis időnként előfordul immunkompetens egyének esetében is [16]. Az incidenciát illetően ellentmondásos adatokat talál- hatunk az irodalomban. A malignus hematológiai betegségben szenvedőknél az előfordulási arány nő $[2,6]$, de ugyanakkor a diabeteszes betegek között, azok számának emelkedése ellenére számuk nem növekszik. Ennek hátterében vélhetően az szerepel, hogy ezen betegek nagy része valamilyen statin terápiában is részesül. Ismert, hogy a statinok in vitro számos Zygomycetes osztályba tartozó faj növekedését gátolják $[1,5]$. A mucormycosisnak különböző klinikai formái vannak, leggyakoribb a rhino-maxillaris, illetve a rhino-oculocerebralis forma. Főleg inhaláció útján kerülnek a szervezetbe, a saprophyta mucor fajok gyakran megtalálhatók a felső légutakban, de egészségesek esetében többnyire nem patogének. A spórák bejuthatnak még percutan módon is traumák, bőrsérülések, rovarcsípés útján, injekcióval (például intravénásan drogot használók) vagy a tápcsatornán keresztül, fertőzött élelmiszerrel $[11,16]$. Inhalációt követően az orrüregben a spórák fonalakká alakulnak, invazívvá válnak és primer rhino-orbitocerebralis formában szétterjedhetnek az orrmelléküregekben. A paranasalis sinusokból direkt lágyrész-invázió útján vagy az erek mentén továbbterjedhetnek az orbita felé, illetve cranialis irányba. A sinus sphenoidalis falán keresztül vagy akár a lamina cribrosán át bejutva a koponyába, többszörös agytályogot okozhatnak $[8,13]$. A szaporodó gombafonalak éraffinitása miatt intraarteriális terjedéssel kell számolni. 


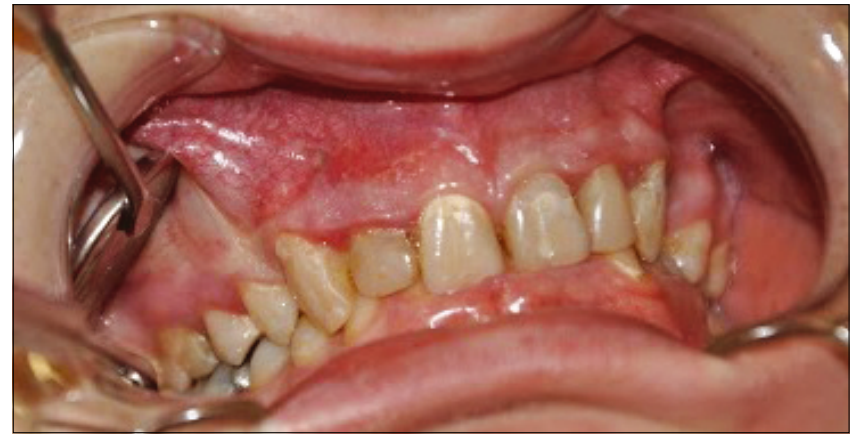

1. ábra: Az 1.6-os fog eltávolítását és sinus revíziót megelőző preoperatív állapot

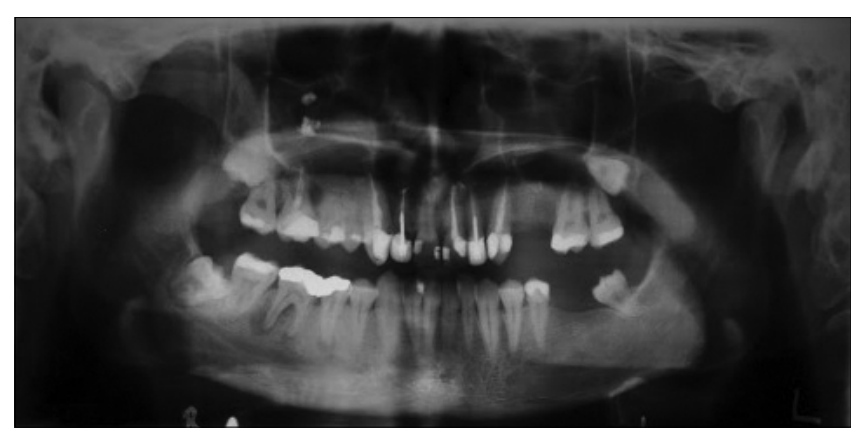

2. ábra: Az 1.6-os fog eltávolítását és sinus revíziót megelőző preoperatív OP felvétel. Jól látható a jobb oldali sinus maxilláris fedettsége és a benne található idegen testnek imponáló elváltozás

Az erekben fibrin válik ki, ennek következménye lehet a „mucorthrombus”, az artéria elzáródása, majd következményes iszkémia, szöveti nekrózis. Angioinvazív terjedésükkel az agyi erek trombózisát okozhatják. Kezdetben a klinikai tünetek nem jellegzetesek, féloldali heveny sinusitis, periorbitális ödéma, bőrpír. A betegség progressziójától függően előfordulhat ptosis, kitágult pupilla, a külső szemizmok bénulása, látásvesztés, fekete, nekrotikus keményszájpad és processus alveolaris és orrkagylók. Sinus sphenoidalis trombózis, illetve agytályog esetén központi idegrendszeri tünetek észlelhetők. A kezdeti stádiumban végzett képalkotó vizsgálatok lelete gyakran negatív, illetve nem sugallja mucormycosis jelenlétét [14]. A diagnosis felállításához a hisztológiai vizsgálat eredménye - a speciális szövettani kép miatt - önmagában is elegendő lehet: széles, szabálytalan alakú, ritkán szeptált, derékszögben elágazódó gombafonalak [11]. A gombafonalak PASsal, Grocott-féle ezüstözéssel festődnek. A kórkép kezelésében legfontosabb a minél korábban megkezdett komplex terápia. Ennek részei: antifungális kezelés (elsőként választandó szer az amphotericin-B lipid formulációja), sebészi terápia, illetve az alapbetegség kezelése, amely hosszú hónapokig tarthat. Sikeres kezelésében kulcsfontosságú a szoros interdiszciplináris (infektológia, szemészet, fül-orr-gégészet, mikrobiológia, patológia, idegsebészet, neurooftalmológia) együttmúködés. Esetünket a kórkép ritka előfordulása és a társ-szak- mák közötti (alapvetően fontos) együttmüködés bemutatása miatt tartjuk közlésre érdemesnek.

\section{Esetismertetés}

28 éves férfi páciens a maxilla jobb oldalán elhelyezkedő arcduzzanattal és fájdalommal jelentkezett. Anamnézisben említésre méltó nem szerepelt. A klinikai és radiológiai (2. ábra) vizsgálat alapján, a jobb oldali felső első moláris fogból kiinduló periostitis volt valószínúsíthető. A panorámaröntgen-felvételen a 1.6-os fogban inkomplett gyökértömés, a periapikális térben krónikus gyulladás volt látható. A röntgenfelvételen a jobb oldali arcüregben radio-opak képlet jelent meg, melyet a sinusban visszamaradt gyökértömő anyagnak tartottunk. A jobb oldali arcüreg fedettséget mutatott. Az idegen testre, valamint a krónikus arcüreggyulladásra való tekintettel a páciensről a tervezett beavatkozás előtt CBCT felvételt (3-6. ábra) készítettünk. Az akut panaszok megszúnését követően [intraorális incízió és egy hétig antibiotikumos terápia történt (Amoxicillin 875 mg + Klavulánsav $125 \mathrm{mg} 2 \times 1$ )] mútéti feltárásból (1. és 7. ábra) a jobb felső hatos fogat eltávolítottuk és sinus revíziót végeztünk (8-9. ábra). Az arcüregből egy körülbelül babnyi méretü, rugalmas tapintatú, nekrotikus felszínű szövetet távolítottunk el, a képletet hisztológiai vizsgálatra küldtük. Az arcüregben lévő, radiológiailag gyökértömő anyagnak imponáló elváltozás szövettani vizsgálata megcáfolta feltételezésünket. A hisztológiai eredmény mucormycosis volt (10-11. ábra). A páciens posztoperatív időszaka zavartalan volt, a seb per primam gyógyult. A szövettani eredményre való tekintettel a pácienst további kezelés céljából az Egyesített Szent László és Szent István Kórház-Rendelőintézet I. Infektológiai Osztályára irányítottuk. A pácienst tovább vizsgálták, az esetleges egyéb háttérbetegségeket kizárták. A páciens több alkalommal megjelent kontrollvizsgálaton, aktív mucormycosis fertőzésre utaló jelet azonban nem találtak. Tekintettel erre, valamint a páciens negatív anamnézisére, további ellátást nem tartottak indokoltnak.

\section{Összefoglalás}

A mucormycosis fulmináns, opportunista gombafertőzés, mely fogékony szervezetben jelentős mortalitással rendelkezik. A kórkép kezelésében elsősorban nem fogorvosoknak, szájsebészeknek van szerepe, de a betegség lokalizációja miatt szükséges ismerni. A sinus maxillárisban elhelyezkedő, radiológiai felvételen radioopak képletek differenciál diagnosztikai problémákat okozhatnak, amelyek esetén gombafertőzésre is gondolnunk kell. A komplex terápia minél hamarabb történő megkezdése mucormycosis esetén döntően befolyásolja a prognózist, ezért az interdiszciplináris együttmúködést haladéktalanul el kell kezdeni. 


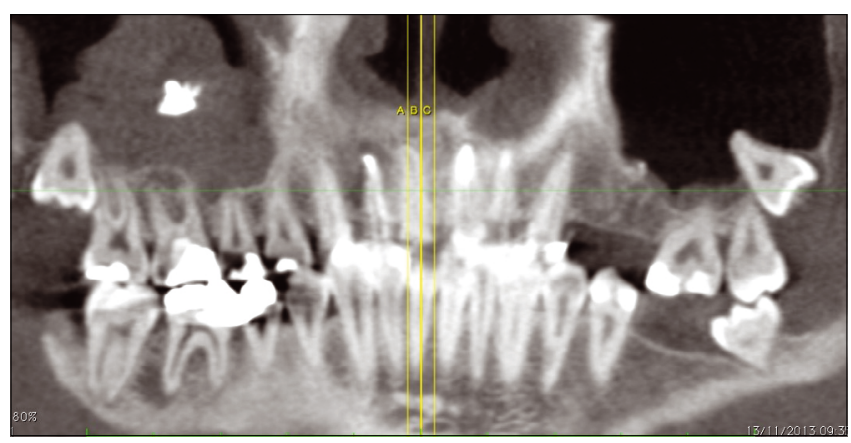

3. ábra: A sinus revíziót megelőző CBCT felvétel

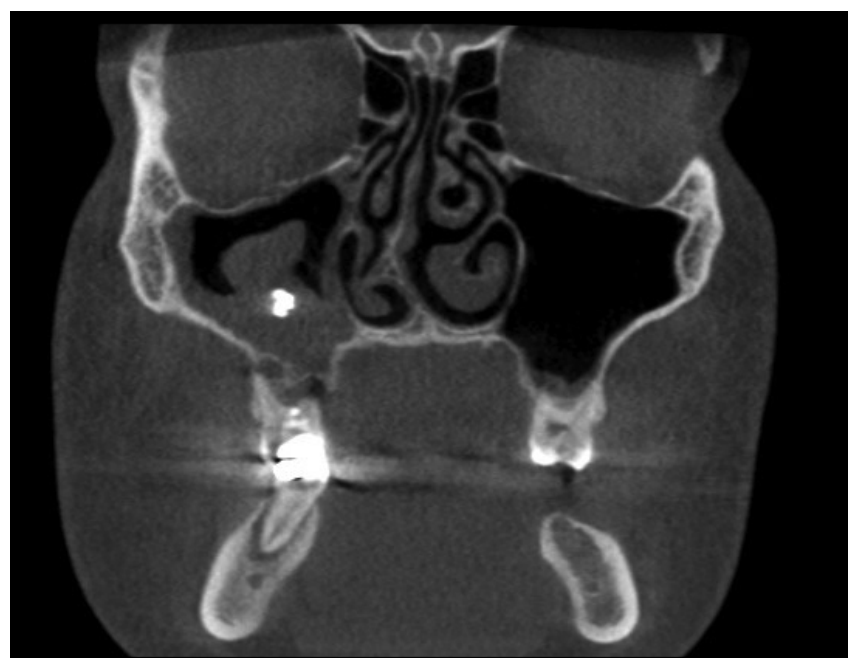

4. ábra: A sinus revíziót megelőző CBCT felvétel, koronális metszet

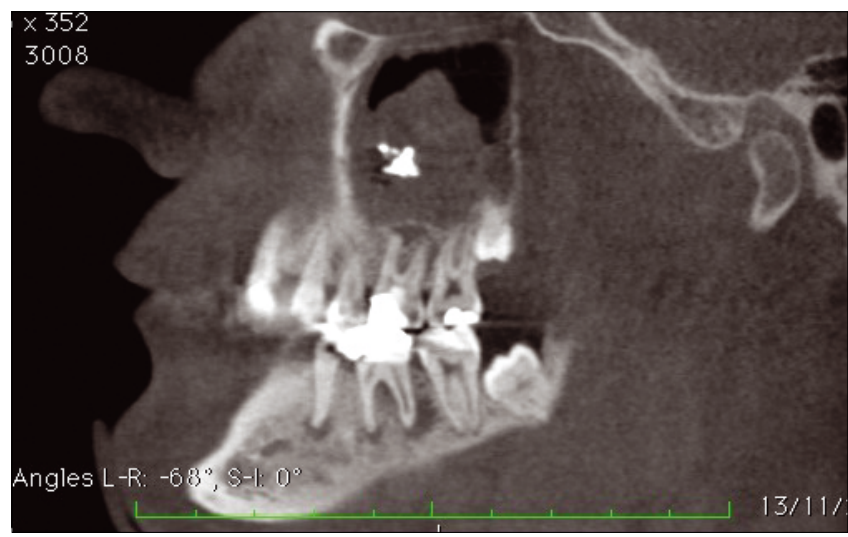

5. ábra: A sinus revíziót megelőző CBCT felvétel, szagittális metszet

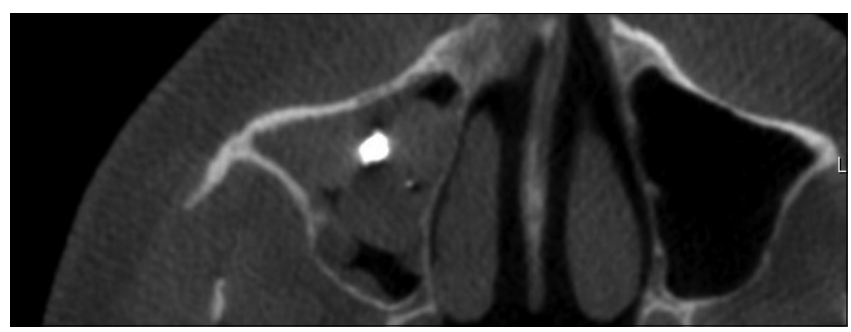

6. ábra: A sinus revíziót megelőző CBCT felvétel, horizontális metszet

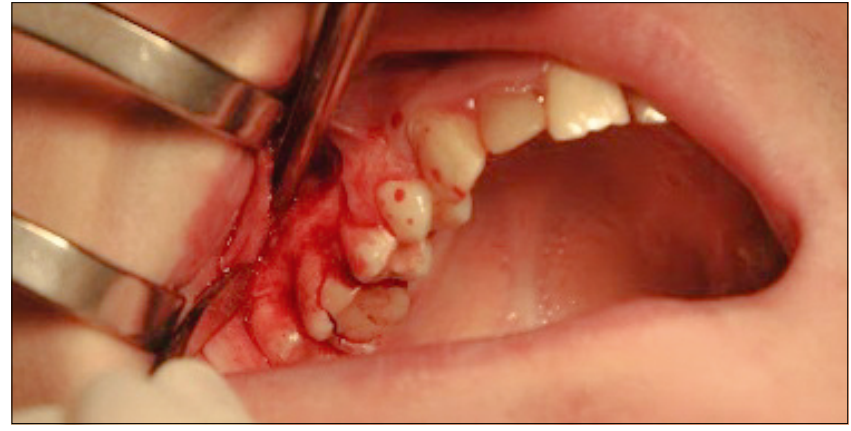

7. ábra: Lebenyképzés, Wassmund szerint

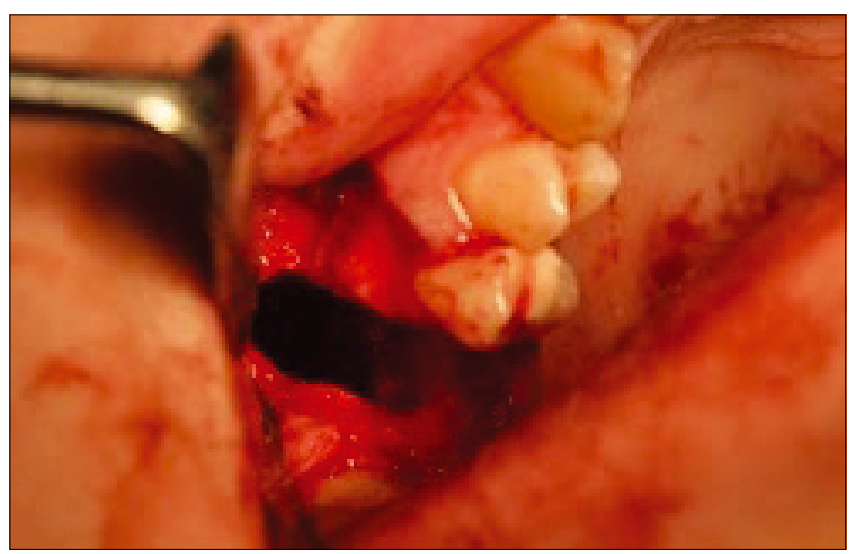

8. ábra: 1.6-os fogat extraháltuk. Az alveolaris szeptumot és a bukkális kortikális egy részét eltávolítottuk.

A létrehozott nyíláson keresztül sinus revíziót végeztünk.

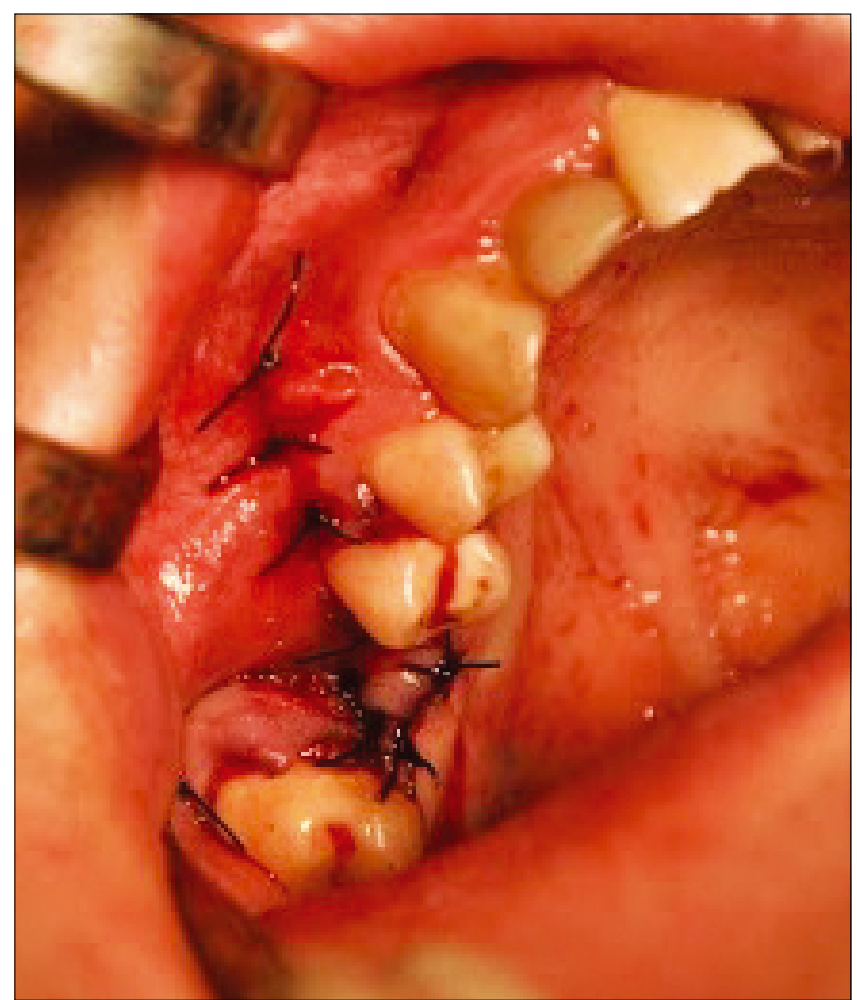

9. ábra: A sebet per primam, horizontális matrac, valamint egyszerű csomós öltésekkel zártuk. 


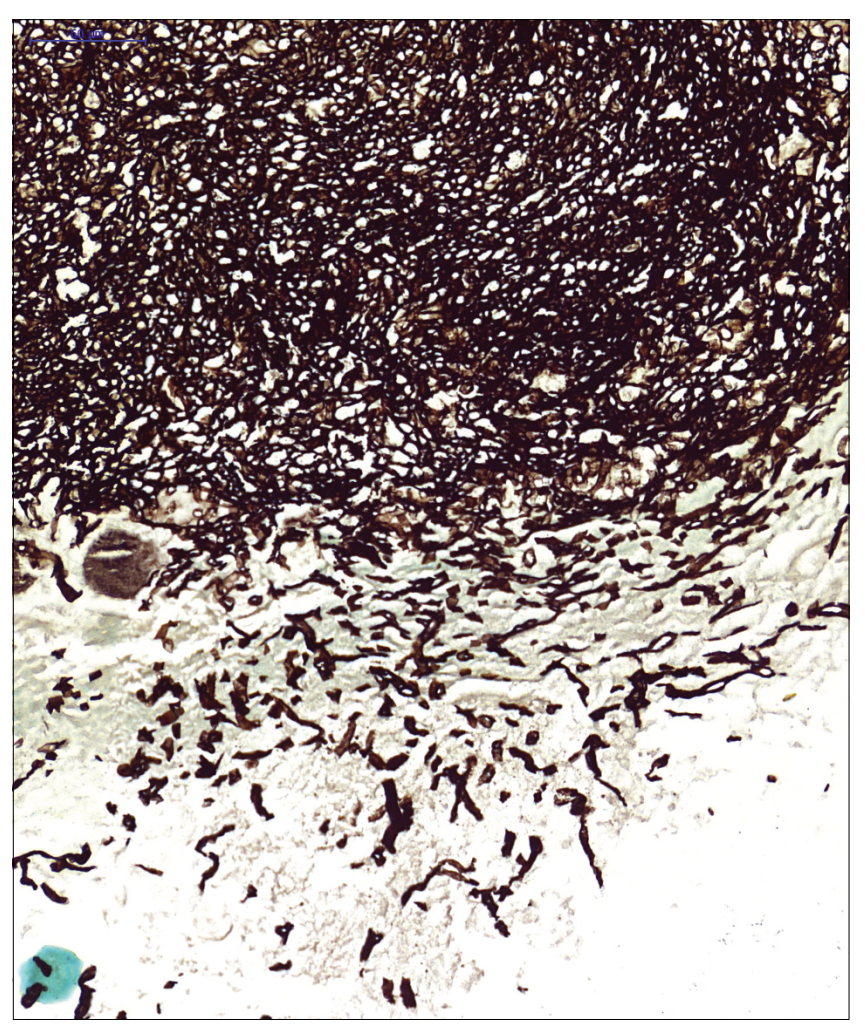

10. ábra: Az arcüregből eltávolított idegen testnek imponáló terime szövettani metszete, HE festéssel, 40x-es nagyításban.

Láthatók a mucormycosisra jellemző széles, szabálytalan alakú, ritkán szeptált, derékszögben elágazódó gombafonalak.

\section{Irodalom}

1. Chamilos G, Lewis RE, Kontoyiannis DP: Lovastatin has significant activity against zygomycetes and interacts synergistically with voriconazole. Antimicrob Agents Chemother 2006; 50: 96-103.

2. Greenberg RN, Mullane K, Burik JAH et al: Posaconazole as salvage therapy for zygomycosis. Antimicrob Agents Chemother 2006; 50: 126-133.

3. HarRIS JS: Mucormycosis. Report of a case. Pediatrics 1955; 16 : 857-867.

4. Koklu E, Akcakus M, Torun YA, Tulpar S: Primary Gangrenous Cutaneous Mucormycosis of the Scalp in a Child. Pediatric Emergency Care 2008; 24: 102-104.

5. KonTOYIANNIS DP: Decrease in the number of reported cases of zygomycosis among patients with diabetes mellitus: a hypothesis. Clin Infect Dis 2007; 44: 1089-1090.

6. KontoyiannIS DP, LIONAKIS MS, Lewis RE et al: Zygomycosis in a tertiary-care cancer center in the era of Aspergillusactive antifungal therapy: A case-control observational study of 27 recent cases. J Infect Dis 2005; 191: 1350-1360.

7. Lakatos B, Nikolovara R, Ocskay L, Csomor J, Prinz Gy: Rhinocerebralis zygomycosisból gyógyult diabeteses férfi esete. Orv Hetil 2010; 39: 1591-1595.

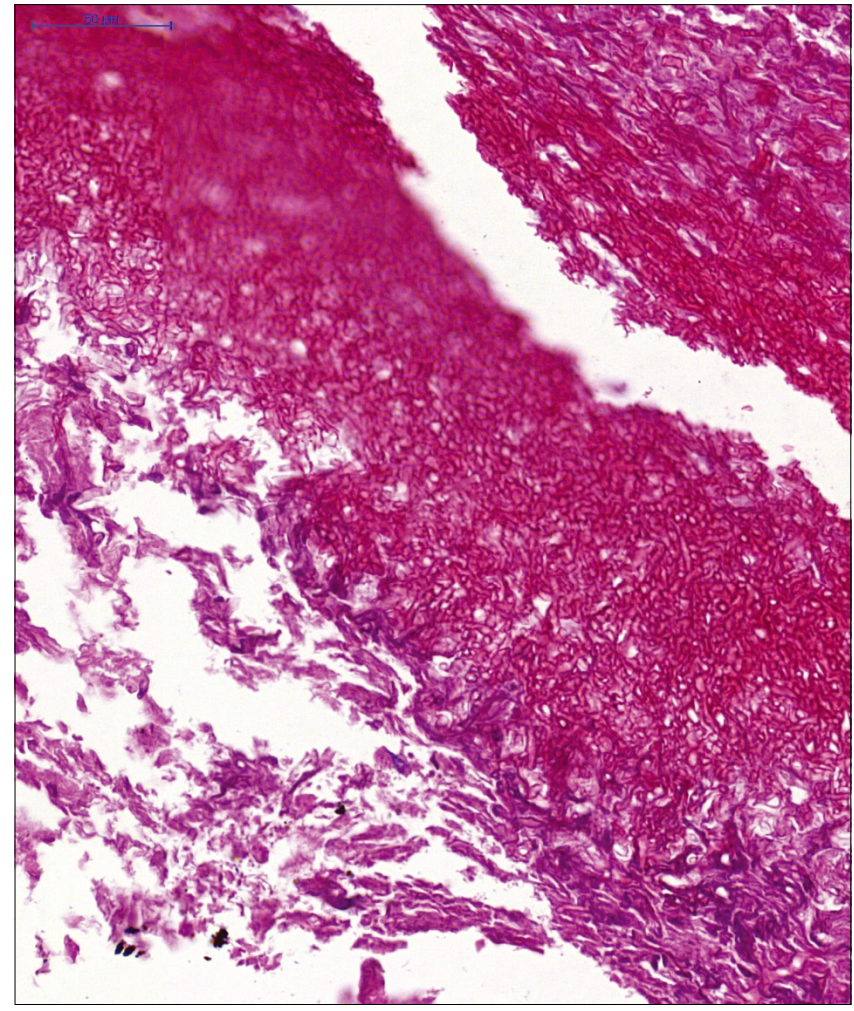

11. ábra: Az arcüregből eltávolított idegen testnek imponáló terime szövettani metszete, Grocott-festéssel, 40x-es nagyításban.

Láthatók a mucormycosisra jellemző széles, szabálytalan alakú, ritkán szeptált, derékszögben elágazódó gombafonalak.

8. Liang K, Tleyjeh I, Wilson W, Roberts G, Temesgen Z: Rhino-orbitocerebral mucormycosis caused by Apophysomyces elegans. J Clinic Microbiol 2006; 44: 892-898.

9. Maliman N, Reyes CV, Rippon JW: Osteomyelitis secondary to cutaneous Mucormycosis. Am J Dermatopathol 1984; 6: 479481.

10. Paltauf A: Mucormycosis mucorina. Virchows Arch Pathol Anat 1885; 102: 543-564.

11. Ribes J, Vanover-Sams C, Baker D: Zygomycetes in human disease. Clin Microbiol Reviews 2000; 4: 236-301.

12. Roden MM, ZaOUtIS TE, Buchanan WL et al: Epidemiology and outcome of zygomycosis: A review of 929 reported cases. Clin Infect Dis. 2005; 41: 634-653.

13. Rumboldt Z, Castillo M: Indolent intracranial mucormycosis. Am J Neuroradiol 2002; 23: 932-934.

14. Spellberg B, Edwards J, lbrahim A: Novel perspectives on mucormycosis: Pathophysiology, presentation and management. Clin Microbiol Rev 2005; 18: 556-569.

15. WILLIAM PB: Rhinocerebral mucormycosis: http://www.emedicine. com

16. WINGARD J: Zygomycosis: epidemiology and treatment options. Adv Stud Med 2006; 6: 526-530. 


\section{BérCzy K, LőrinCz Á, FónYAd L, PRINZ GY}

\section{Diagnostic problems of the mucormycosis of the maxillary sinus}

Case presentation

Mucormycosis is a fulminant opportunistic infection with significant mortality in susceptible individuals. Although mortality rates vary widely (30 to $100 \%$ ) according to professional literature, recently in instances with no central nervous system (CNS) involvement the survival rate averages varies between 50 and $80 \%$ owing to complex therapy. With CNS involvement, however, the fatality rate is over $80 \%$. Predisposing diseases include diabetes mellitus, malnutrition, hematological diseases, neutropenia, burns, surgical procedures, antibiotic treatments, long-term steroid therapy and immunosuppressive therapy. Mucormycosis may at times arise even in immunocompetent individuals. It has diverse clinical forms with the most frequent forms being rhino-maxillary and rhino-oculocerebral (the latter of which is characterized by a high mortality rate). They mainly enter the body through inhalation, with saprophytic mucor species often demonstrable in the upper respiratory tracts, which are nevertheless non-pathogenic in most healthy individuals. The spores may also enter percutaneously through traumas, skin lesions, insect bites, or injections (e.g. through intravenous drug use), as well as via the alimentary tract with contaminated foodstuff. The prognosis can be improved by a quick establishment of the diagnosis, the quick initiation of the therapy and treatment of the underlying disease. Although first and foremost the recognition and treatment of the disease does not rest with dentists and oral surgeons, in order to localize the disease it is important to examine it from a differential diagnostic point of view and interdisciplinary cooperation may also be required in a complex treatment. Our aim is to introduce mucormycosis in our case report study.

Key words: mucormycosis, sinusitis, invasive fungal infection 